\title{
Food Security, Productivity and Gender Inequality
}

Link to publication record in Manchester Research Explorer

\section{Citation for published version (APA):}

Agarwal, B. (2011). Food Security, Productivity and Gender Inequality. (Working Paper, forthcoming as book contribution).

\section{Citing this paper}

Please note that where the full-text provided on Manchester Research Explorer is the Author Accepted Manuscript or Proof version this may differ from the final Published version. If citing, it is advised that you check and use the publisher's definitive version.

\section{General rights}

Copyright and moral rights for the publications made accessible in the Research Explorer are retained by the authors and/or other copyright owners and it is a condition of accessing publications that users recognise and abide by the legal requirements associated with these rights.

\section{Takedown policy}

If you believe that this document breaches copyright please refer to the University of Manchester's Takedown Procedures [http://man.ac.uk/04Y6Bo] or contact uml.scholarlycommunications@manchester.ac.uk providing relevant details, so we can investigate your claim.

\section{OPEN ACCESS}




\section{FOOD SECURITY, PRODUCTIVITY \\ AND \\ GENDER INEQUALITY}

Bina Agarwal

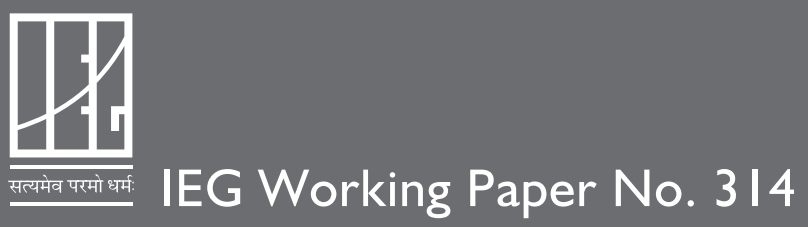





\title{
FOOD SECURITY, PRODUCTIVITY AND \\ GENDER INEQUALITY1
}

\begin{abstract}
This paper examines the relationship between gender inequality and food security, with a particular focus on women as food producers, consumers, and family food managers. It sets the discussion against the backdrop of the recent food crises, the vulnerabilities created by regional concentrations of food production, imports and exports, the feminization of agriculture, and the projected effect of climate change on crop yields. It examines the constraints women face as farmers in terms of their access to land, credit, production inputs, technology, and markets. Bridging productivity differentials between male and female farmers, by helping women overcome production constraints, would significantly increase agricultural output. This becomes an imperative, given the feminization of agriculture. The paper spells out the mechanisms, especially institutional, for overcoming the constraints and inequalities women face as producers, consumers, and home food managers. Institutionally, a group approach to farming would, for instance, help women and other small holders enhance their access to land and inputs, benefit from economies of scale, and increase their bargaining power. Other innovative solutions discussed here include the creation of public land banks that empower the small holder and the setting up of resource centres that cater especially to small women farmers.
\end{abstract}

Key words: Food security, gender inequality, gender differentials in production constraints, regional imbalance in food production, group farming

JEL codes: J16, J43, Q13, Q15, Q18

\footnotetext{
${ }^{1}$ This is an updated and revised version of a working paper, Agarwal (2011). It is forthcoming as a chapter in Herring, R. (ed): Handbook of Food, Politics and Society (New York: Oxford University Press).
} 



\section{INTRODUCTION}

Of the many global challenges we face today, perhaps the most significant and of the longest duration is that of providing food security and eliminating hunger. This challenge is compounded by developments such as the rise and volatility of food prices; the shift from foodcrops to biofuels in major food exporting countries; the neglect of agriculture in many developing countries, especially in terms of investment in infrastructure; and the looming threat of climate change with its predicted adverse effects on food production.

These developments are both cause for serious concern and an opportunity for change, since there is now a renewed global interest in agriculture to reduce the constraints to economic growth and improve food security. There is also a growing recognition of the need to tap the potential of small farmers, a vast number of whom are women. For sustainability we need long-term efforts to increase production, stabilize food availability, and improve distribution. Here the role of women as farmers, as consumers, and as family food managers can prove pivotal.

Food security requires both the availability of adequate food and economic and physical access to what is available. The quality of food (e.g. adequate micronutrients) is also important. In each respect, women play a critical role. They are major food producers and hence significant contributors to food availability. Their access to food has an important bearing on their own and their family's food security. And nutritional quality is of particular importance for women, given their special needs during pregnancy and lactation.

This paper examines the relationship between gender inequality and food security with a particular focus on the following dimensions: (1) women as food producers, the production constraints they face as farmers, and the potential for increasing agricultural output globally if the constraints are overcome; (2) women as consumers and key managers of food in the home, and the implications of their unequal access to food; and (3) the mechanisms, especially institutional, for overcoming the constraints and inequalities women face as producers, consumers, and family food managers. Before focusing on the gender dimensions, however, I outline some general factors that impinge on the question of food security today. 


\section{SOME GENERAL FACTORS}

A key factor, which has an important bearing on long-term prospects of global food security, is the regional concentration of foodgrain production and exports. In 2008, Asian farmers produced 90 per cent of the world's rice and around 40 per cent of its wheat and total cereals. But most Asian countries consume what they produce, and the exports come from only a few. Sixty-five per cent of all cereal exports came from North America and Europe (Figure 1).

Figure 1: Production, exports and imports of total cereals, 2008 (\%)

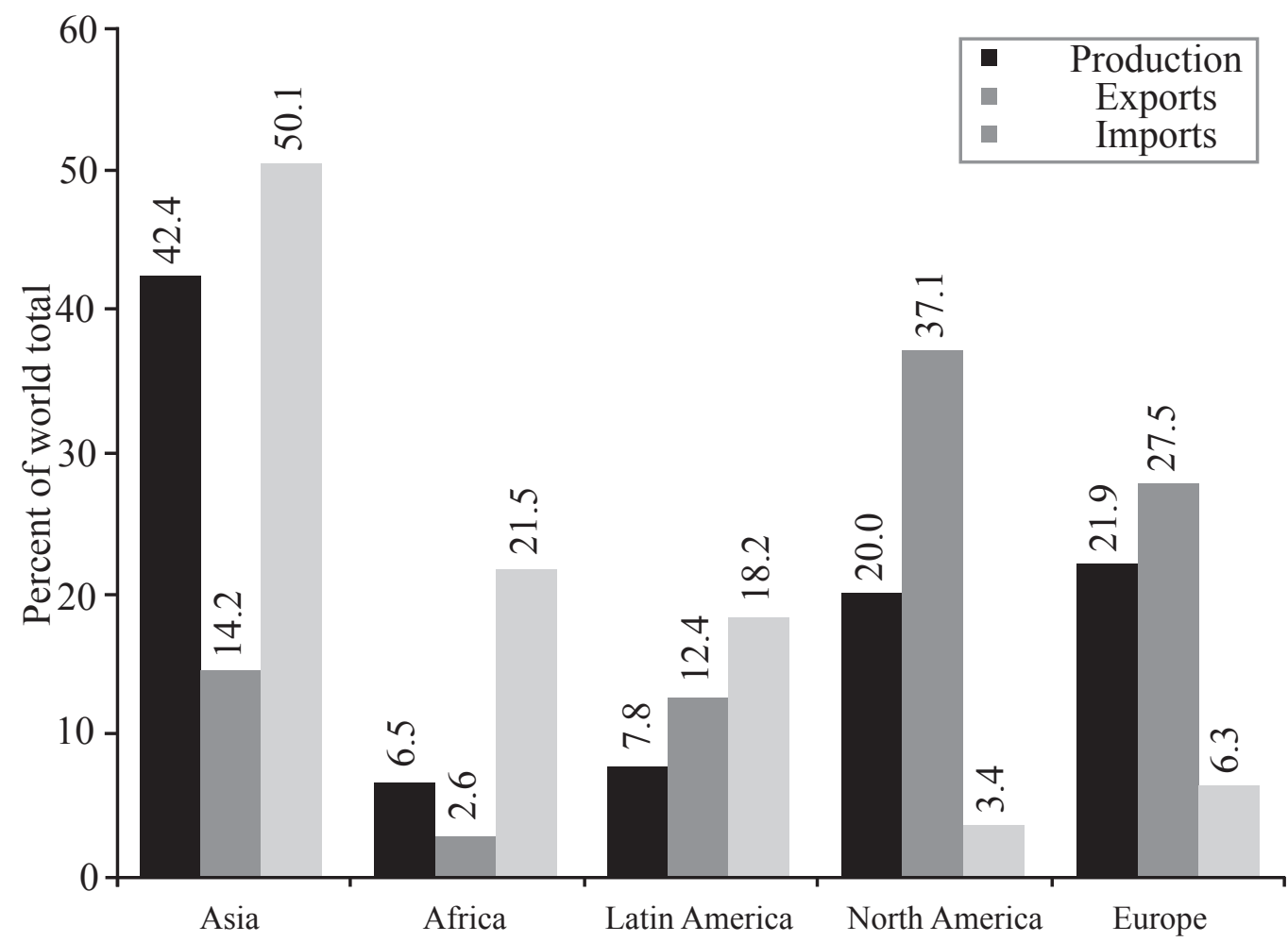

Source: Based on FAO statistics (http://faostat.fao.org)

This regional concentration makes food deficit regions over-dependent on certain countries. It also leaves food importing countries vulnerable to policies in the exporting countries. For instance, if the latter shift large areas from foodgrains to biofuels, or manage their agriculture inefficiently, or cut exports to deal with their own needs, or do little to control speculative hoarding, the impact would be felt by the importing countries. Adverse weather conditions can compound these other effects. In fact, these are exactly the kinds of factors that underlay the $2007-08$ price rise, when the food price index rose by nearly 40 
per cent relative to 9 per cent in 2006 (von Braun 2008). The adverse effects of this price rise fell on foodgrain importing countries and on net buyers of foodgrains within countries (Quisumbing et al. 2008; see also von Braun 2008-09). The worst affected were the poor, especially women and children. By World Bank estimates, the price rise added 105 million to the poor, mostly in South Asia and sub-Saharan Africa (Ivanic and Will 2008). Although the 2007-08 price spike was especially dramatic, the overall upward trend in prices continues and is cause for major concern globally, as is the prospect of price volatility.

To these short-term factors, we need to add long-term ones such as (1) dietary shifts toward meat and milk with rising incomes in developing countries, leading to a higher demand for grain to feed livestock and the land to grow it; ${ }^{2}(2)$ rising world population, which is predicted to be nine billion by 2050; and (3) neglect of agriculture in developing countries over a long period, reflected especially (as mentioned) in falling public investment in agricultural infrastructure and services.

In addition, we have the predicted adverse effects of climate change on foodgrain production. The impact is expected to be especially negative in South Asia and subSaharan Africa. Assessments by the International Food Policy Research Institute (IFPRI) in Washington DC, for instance, show that in 2050, climate change relative to the no-climatechange scenario could lower production of rice, wheat, and maize by around 14 per cent, 49 per cent, and 9 per cent respectively in South Asia; and by 15 per cent, 36 per cent, and 7 per cent respectively in sub-Saharan Africa (IFPRI 2009). ${ }^{3}$ Indeed, climate change, coupled with growing demand for food as populations and incomes grow, is also expected to trigger price rise in the major staples_rice, wheat, and maize. These price increases need not translate to increased production, given supply side constraints faced by small producers, who constitute a vast proportion of farmers in developing countries. Also, higher feed prices will raise meat prices. Extraordinary efforts are needed to meet the food security demands of the estimated nine billion people by 2050—without climate change. With climate change, this is even more imperative. If food output lags behind population, per capita calories available in the developing world in 2050 will be lower than in 2000 . By some estimates, this could result in 20 per cent higher child malnutrition than would be the case with the no-climate-change scenario (IFPRI 2009). Indeed, even with the best efforts at mitigating climate change, the poor, and especially women and children, are

\footnotetext{
${ }^{2}$ Halving meat consumption in the OECD countries, Brazil, and China by 2030 could free an estimated 200 million hectares or more of livestock-raising land globally which, if used for non-meat food production, could substantially improve food and nutrition security in developing countries. (Presentation by Mark Rosegrant, Agriculture-NutritionHealth Linkages conference, New Delhi, February 2011)

${ }^{3}$ IFPRI gives various scenarios for (spatially disaggregated) temperature rise, precipitation, and so on. The illustrative estimates cited here are based on data from the National Centre for Atmospheric Research (which uses IPCC information) and do not adjust for 'carbon dioxide fertilization'. Adjusted estimates still give adverse predictions (albeit less so) for yields of major crops in developing countries.
} 
likely to suffer disproportionately. The gender factor is, in fact, a critical one as we look toward the future, since women are significant food producers as well as consumers and home food managers.

\section{WOMEN AS FOOD PRODUCERS}

Agriculture today contributes less than 10 per cent of the GDP of most countries, but continues to be a major source of employment and livelihoods in many. This is especially so in Asia and Africa where the percentage of workers in agriculture remains close to 60 (Figure 2). This divergence in major developing regions between agriculture's GDP contribution and the population it supports means that many are trapped in low-productivity livelihoods. And this trap is gendered, given women's disproportionate dependence on agriculture for a living and its growing feminization.

Figure 2: Percentage of total labour force in agriculture

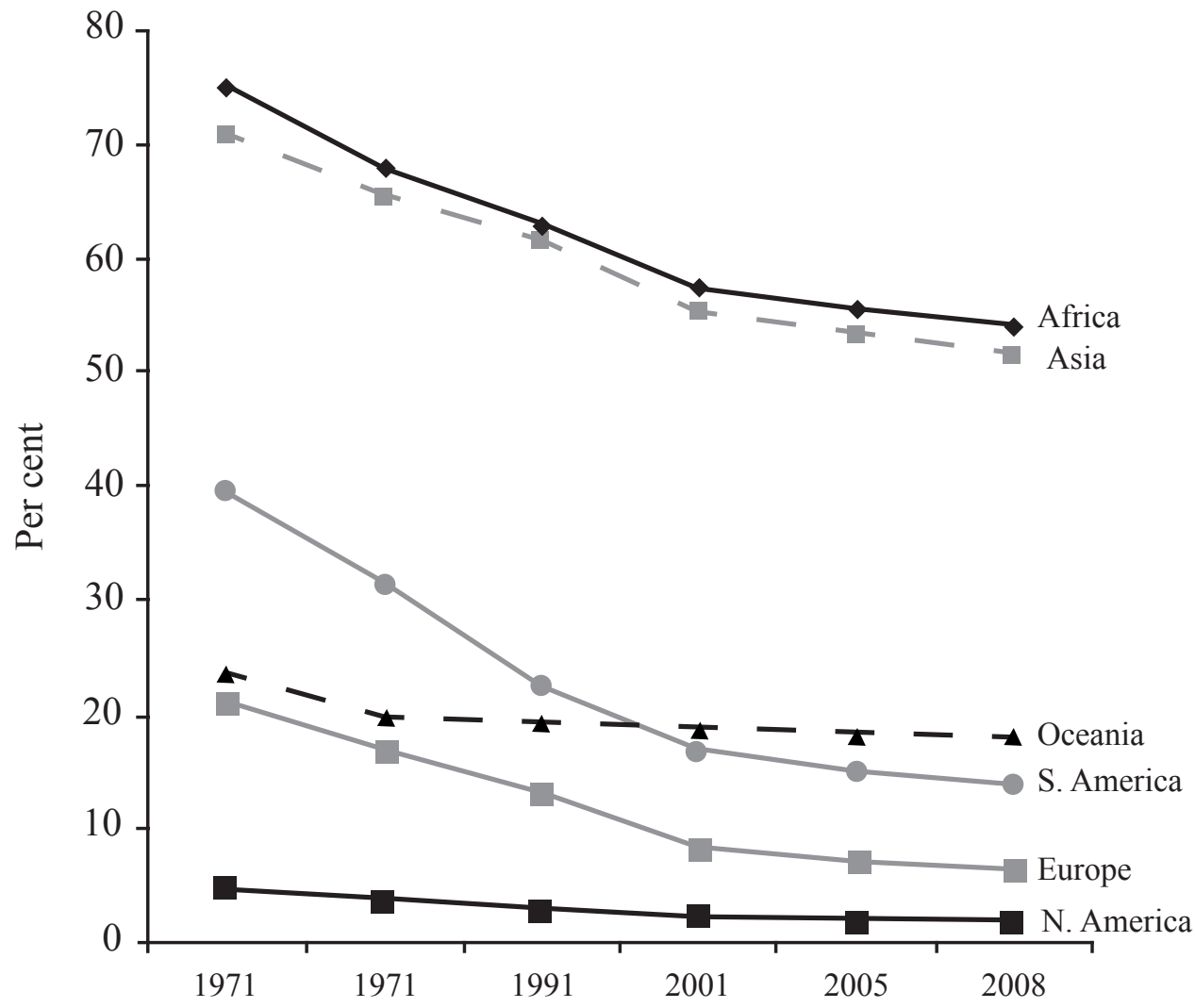

Source: Based on FAO statistics (http://faostat.fao.org) 
Women workers depend much more on agriculture for survival than male workers, due to their lesser access to non-farm jobs. In Africa, for instance, in 2008, 63 per cent of female workers relative to 48 per cent of male workers depended on agriculture-based livelihoods. For Asia, the percentages were 57 for females and 48 for males (Figures 3 and 4). Women also constitute a substantial proportion of the total agricultural labour force. In Asia, for instance, 43 per cent of all farm workers in 2008 were female, with percentages as high as 52 in Cambodia and the Lao People's Democratic Republic, 50 in Bangladesh, 49 in Vietnam, and 48 in China. In the world's major rice-producing and -exporting regions, therefore, almost half the agricultural work force was female. In Africa, again, women form almost 50 per cent of agricultural workers. Moreover, based on time use data for parts of sub-Saharan Africa, India, and China, Doss (2010: 9) finds that women contribute 60-70 per cent of the total labour needed to bring food to the table in developing countries, if we aggregate the time spent on food production, processing, and preparation.

Figure 3: Female agricultural labourers as a percentage of economically active females

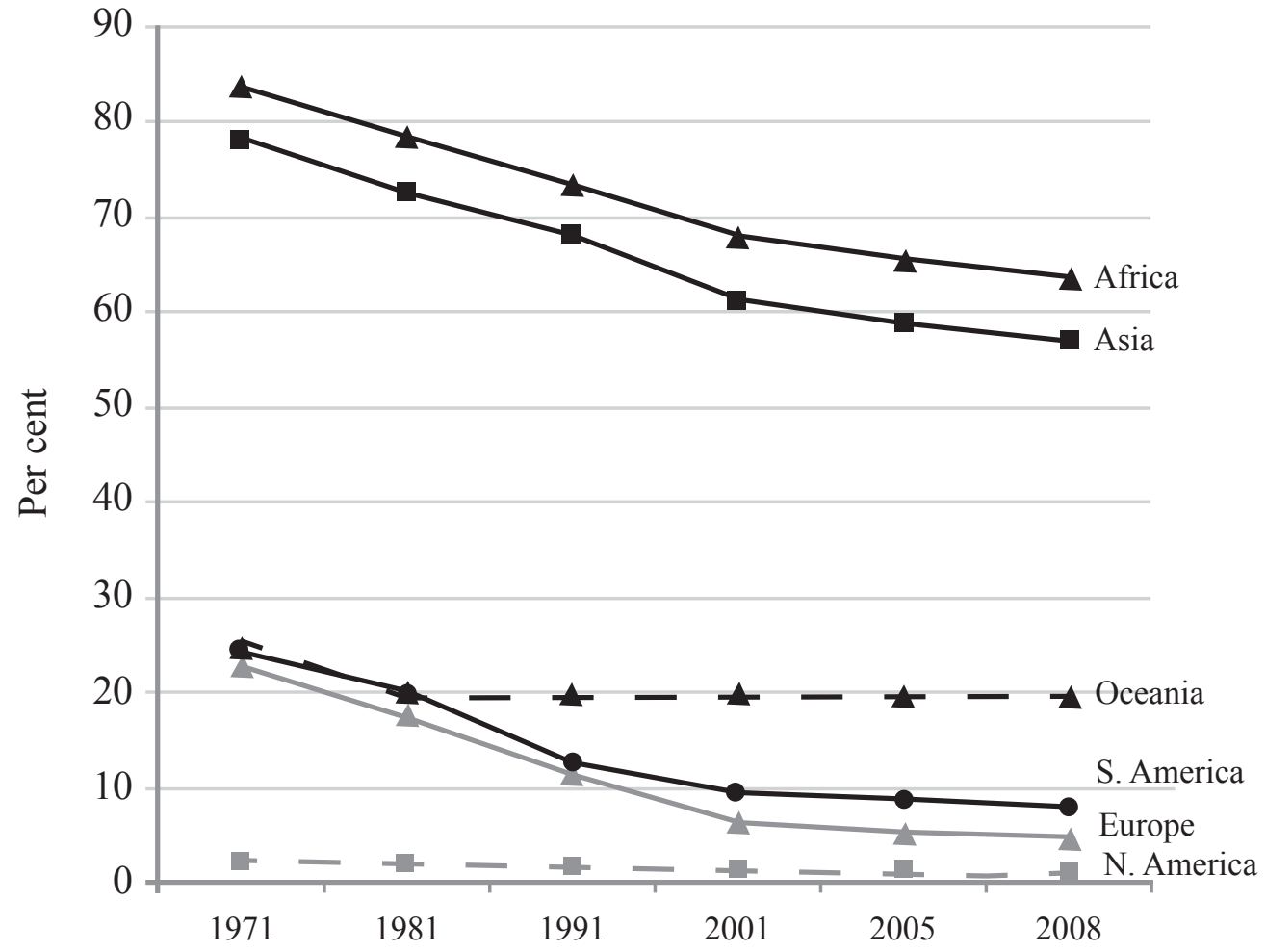

Source: Based on FAO statistics (http://faostat.fao.org) 
Figure 4: Male agricultural labourers as a percentage of economically active males

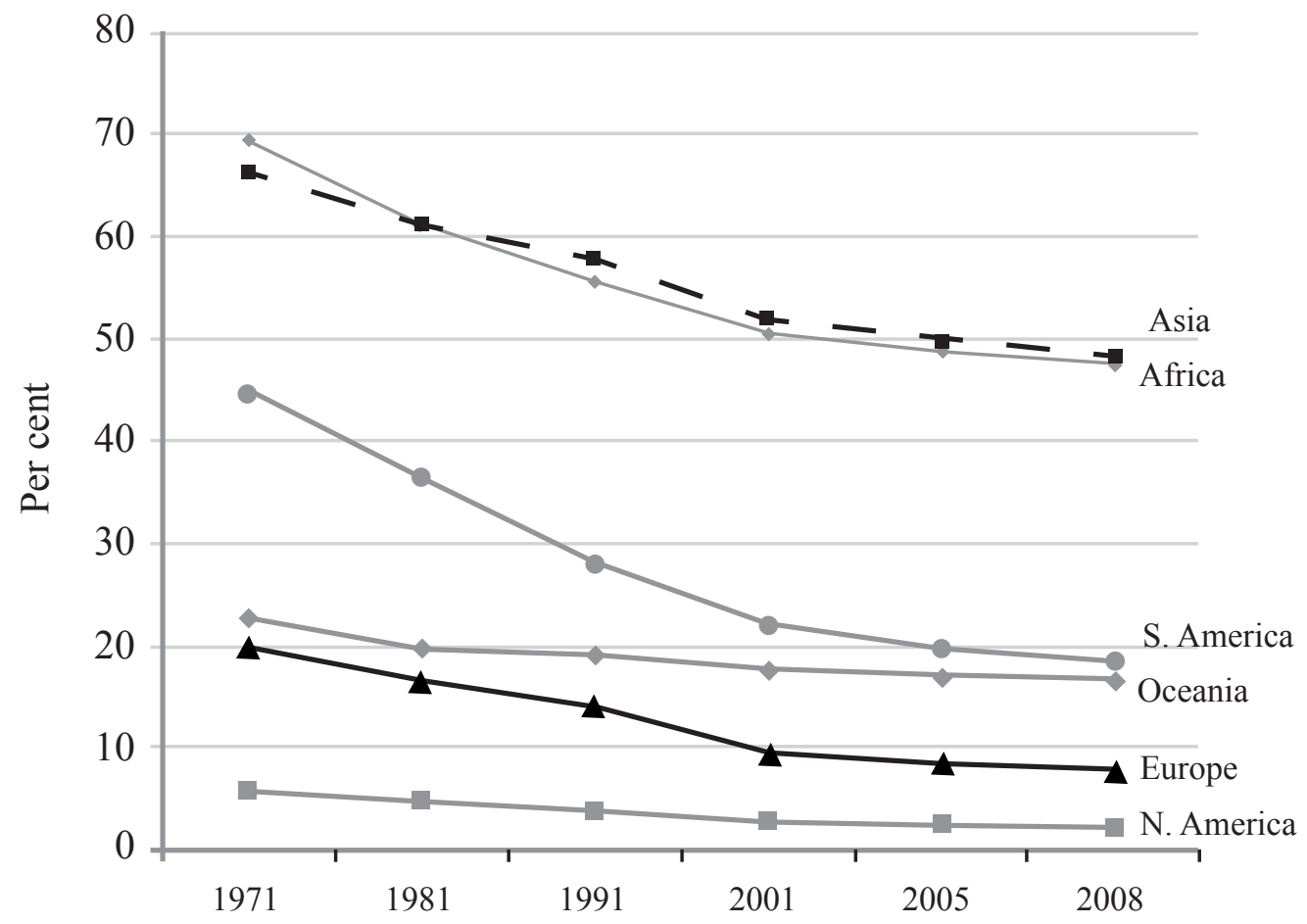

Source: Based on FAO statistics (http://faostat.fao.org)

Indeed, dependence on women's work in agriculture is not only high but growing. Men have been moving to non-farm jobs to a much greater extent than women. Over the past four decades, in all parts of the world except Europe, women workers have been rising as a proportion of the total agricultural work force-in some cases gradually, as in Asia, and in other cases substantially, as in Oceania and South America (Figure 4). In other words, we are seeing a move toward the feminization of agriculture (defined here as a rise in the proportion of women in the total agricultural work force, even if the absolute proportion remains half or below). Clearly, the agrarian transition-the shift of workers from agriculture to industry and services, and from rural to urban areas-that is expected with development has been notably gendered. 
Figure 5: Percentage of females in total agricultural labour force

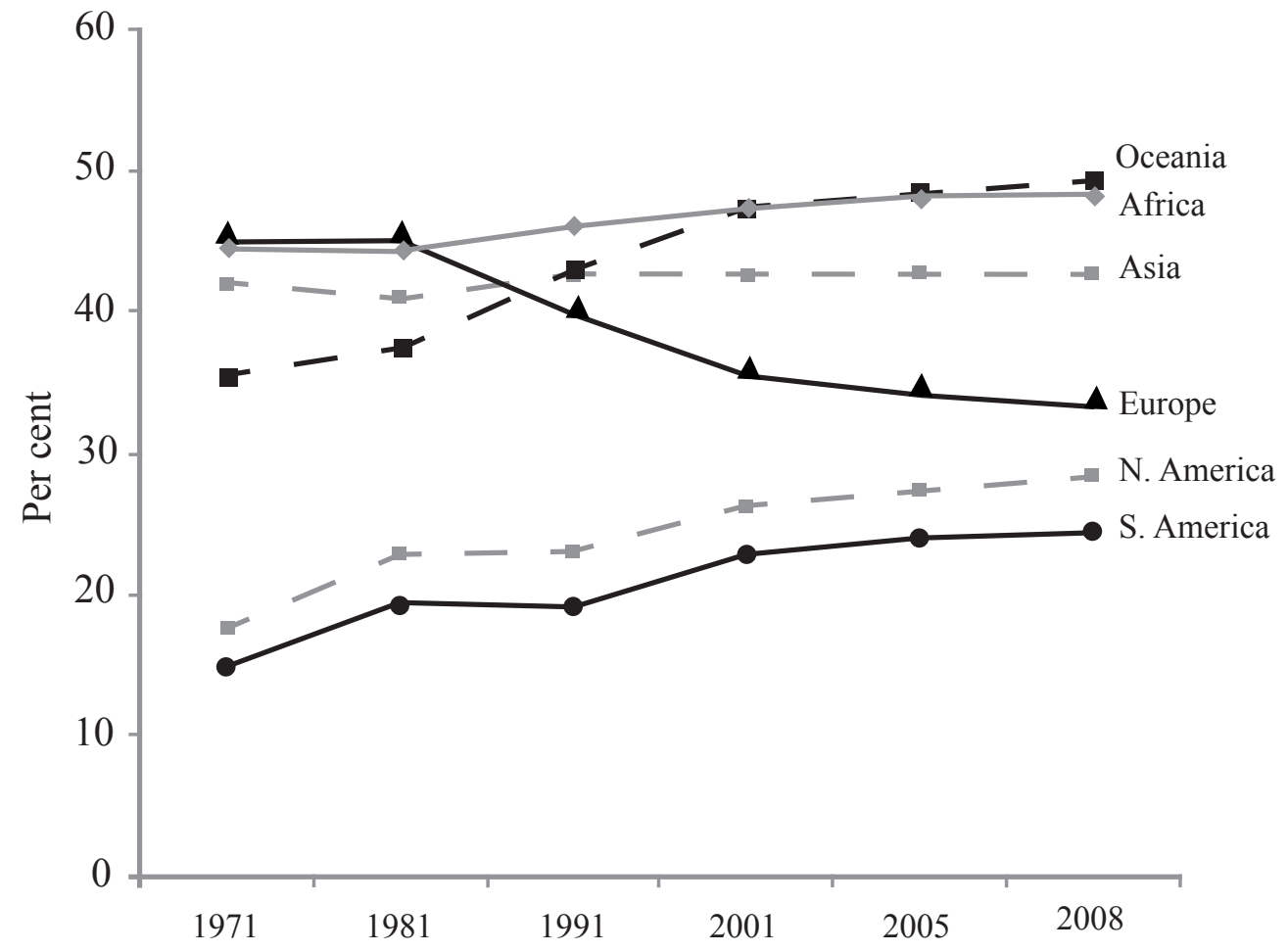

Source: Based on FAO statistics (http://faostat.fao.org)

To revive and sustain agricultural growth as well as adapt to or mitigate climate change, the role of women farmers will thus be central. How effectively they can contribute, however, will depend crucially on their having secure rights in the land they cultivate as well as access to credit and inputs such as fertilizers, irrigation, technology, information on new agricultural practices, and marketing infrastructure.

\section{GENDERED PRODUCTION CONSTRAINTS}

Women farmers face a wide range of gender-specific constraints that affect their productive potential as agricultural workers. First, like the majority of male farmers in developing countries, women operate small farms (in most of South Asia, 80 per cent of farmers cultivate under two hectares). Landlessness has also been growing. Women, in any case, have historically been largely landless, in that most own little or no land themselves. A vast proportion works as unpaid labourers on family farms, or as labourers on the fields of others, or under insecure tenure arrangements on land obtained through the family or 
markets (World Bank 2007: 80). In most regions, 'self-employed' women are typically those working on family farms owned by spouses or male relatives rather than by the women themselves.

Although few countries collect country-level gender-disaggregated data on land or asset ownership, information gleaned from those that do, and from small-scale studies in others, shows a substantial gender inequality. In most of South Asia, except Sri Lanka, for instance, few women own land (Agarwal 1994). In Nepal-a rare country which collected information on landownership by gender in its 2001 census-women were found to own land in only 14 per cent of landowning rural households (Allendorf 2007). In India, although there are no comprehensive data for ownership holdings, the Agricultural Census of 199596 shows that women held only 9.5 per cent of all operational (i.e. cultivated) land holdings (Gol 1995-96). In rural China, women constitute an estimated 70 per cent of the landless, since they are not allotted use rights in community land under the household responsibility system when they relocate on marriage or divorce (Li 2003: 4).

Within Asia as a whole, the gender gap in access to land is much larger in South Asia than in Southeast Asia; and within South Asia the gap is larger in the northern belt (northwest India, Bangladesh and Pakistan) than in south India and Sri Lanka (Agarwal 1994). Underlying these regional variations are differences in laws, culture (especially post-marital residence: distant marriages reduce access), ecology-linked cropping patterns (e.g. women's work contribution is more visible in rice than in wheat cultivation), ethnic and religious diversity, political freedoms, and overall development. In Africa again, we see substantial gender gaps. In Ghana, women hold land in only 10 per cent of the households relative to 16-23 per cent among men (Deere and Doss 2006). In Kenya, women constitute 5 per cent of registered landholders. In Latin America too, there are notable gender inequalities in land ownership (Deere and de Leon 2001; Lastarria-Cornhiel and Manji 2010). But even when women have access to land, their control over it (in terms of rights to lease, mortgage, sell, or use as collateral) tends to be more restricted than men's. ${ }^{4}$

A comparison of land held by male and female-headed households is also revealing. Household surveys, compiled by the Food and Agricultural Organization (FAO) for 20 countries, show that male-headed households (MHHs) operate much larger farms on average than female-headed households (FHHs). In Bangladesh, Ecuador, and Pakistan, for instance, the farm size of male household heads is twice that of female household heads. Moreover, Anriquez (2010) finds that rural FHHs have a higher share of elderly dependents (over 64 years of age) while rural MHHs have a higher share of child dependents. Femaleheaded households are thus likely to be more labour-constrained than MHHs who would

\footnotetext{
${ }^{4}$ See e.g. Agarwal (1994) for South Asia, and Saito et al. (1994) for Nigeria and Kenya. When household heads were excluded from the sample, Saito et al. (1994: 48) found that a substantially lower percentage of female than male farmers had rights to even improve the land, with implications for their relative productivity
} 
have access to youth labour as the children grow to adulthood.

Second, there are well-documented gender inequalities and male biases in women farmers' access to technical information, credit, extension services, critical inputs such as fertilizers and water, and marketing (World Bank 2009; FAO 2011; Peterman et al. 2009). Membership in rural cooperatives that provide inputs is also predominantly male, in most countries (see Saito et al. 1994, among others). In addition, there are significant gender differences in the tools owned by male and female farmers. In Kenya, for instance, the value of farm equipment owned by FHHs was found to be half that owned by MHHs (Saito et al. 1994: 23). In Gambia, under 1 per cent of women farmers are found to own a weeder, seeder or multiuse agricultural implement compared with 12 per cent, 27 per cent, and 18 per cent respectively of male farmers (cited in Peterman et al. 2009: 28).

Third, women face social restrictions in public participation and mobility in many regions (such as in northern South Asia, the Middle East, and North Africa). This adversely affects their ability to freely procure inputs or sell their produce or hire labour. In other words, it restricts their ability to function fully as farmers (Agarwal 1994; FAO 2011; World Bank 2009).

Fourth, these constraints in turn restrict women's ability to take advantage of opportunities for higher value production. Lack of secure land rights and other resources can exclude women farmers from contract farming arrangements, as research in Kenya and Senegal shows (Dolan 2001, Maertens and Swinnen 2009). And in family farms where men hold the contracts, women tend to face heavier workloads while men control the cash generated (Collins 1993; FAO 2011). Women are also less able to adopt high yielding crop varieties and improved management systems due to poorer access to extension services (see Doss 2001, for Africa).

What impact do these constraints have on farm productivity?

\section{GENDER DIFFERENCES IN FARM PRODUCTIVITY}

A substantial body of available evidence indicates that gender inequalities in access to land, agricultural inputs, and support systems can significantly affect farm productivity. The effects are especially revealing in contexts where men and women cultivate both separate and joint plots, as is common in sub-Saharan Africa. For this region, a fair number of studies have measured productivity differences between male and female farmers (Table 1). The studies vary in their methodologies, and in what they measure (individual crop yields, all farm output, or farm incomes), but all of them are based on medium to large samples and statistical analysis. Typically, the comparison is between female and MHHs, but a few studies measure differences between plots managed by men and women within the same extended household. 


\begin{tabular}{|c|c|c|c|c|c|c|c|c|c|}
\hline 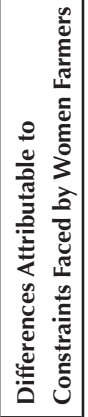 & & 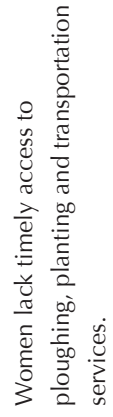 & 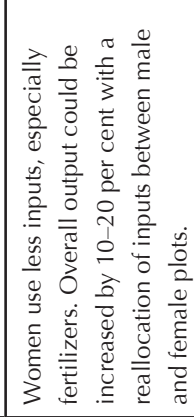 & 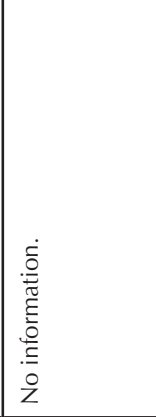 & 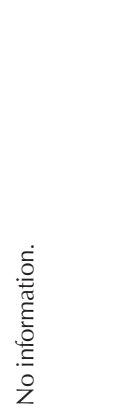 & 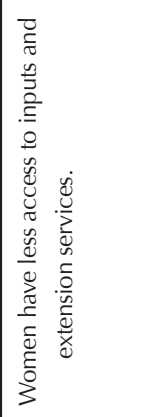 & 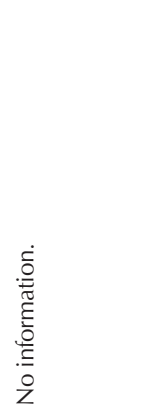 & 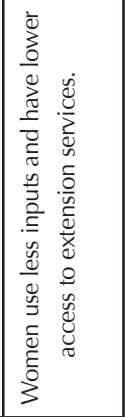 & 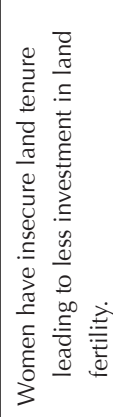 \\
\hline 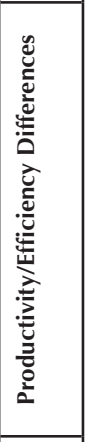 & 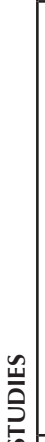 & 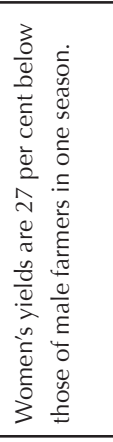 & 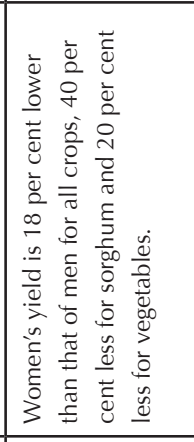 & 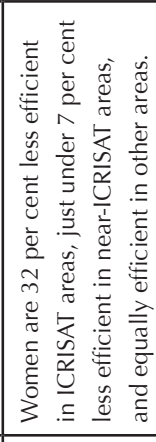 & 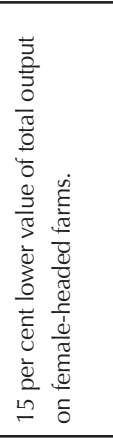 & 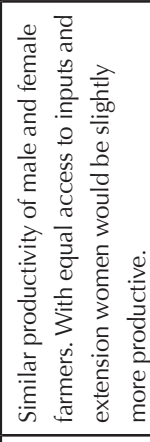 & 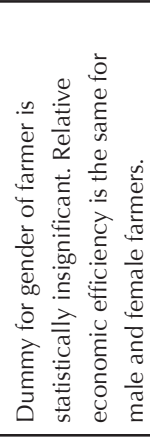 & 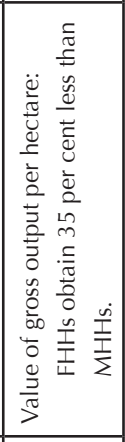 & 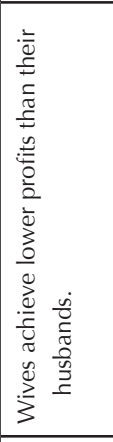 \\
\hline 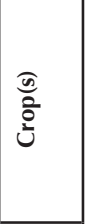 & 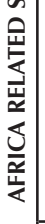 & $\frac{\tilde{u}}{\alpha \underline{\alpha}}$ & 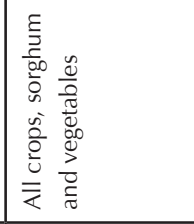 & 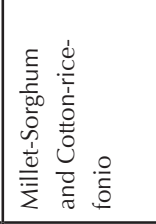 & $\frac{0}{0}$ & $\begin{array}{l}\pi \\
0 \\
0\end{array}$ & $\stackrel{\mathscr{u}}{\frac{\tilde{u}}{4}}$ & 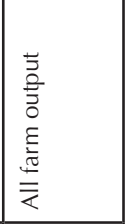 & 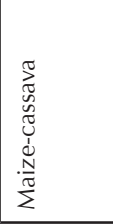 \\
\hline $\begin{array}{l}\frac{0}{\overline{\frac{\nu}{E}}} \\
\text { 心 }\end{array}$ & & 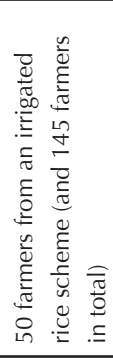 & 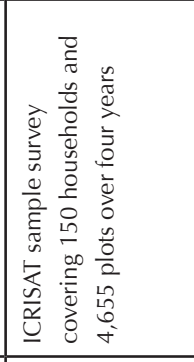 & 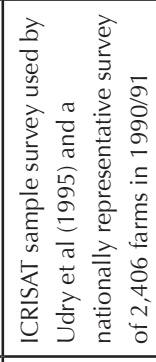 & 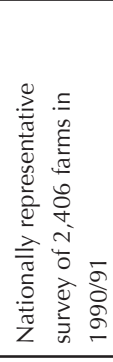 & 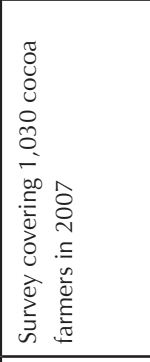 & 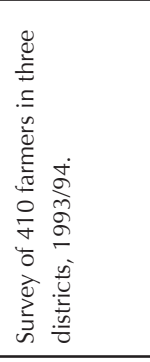 & $\begin{array}{l}\stackrel{n}{1} \\
\text { I } \\
\stackrel{\infty}{\circ}\end{array}$ & \\
\hline 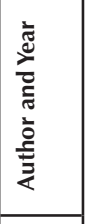 & & 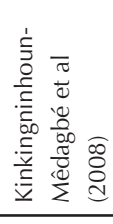 & 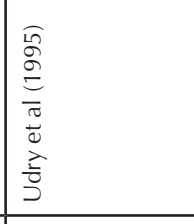 & 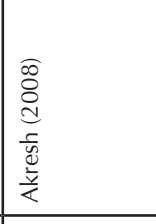 & 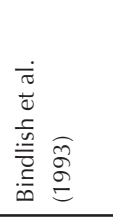 & 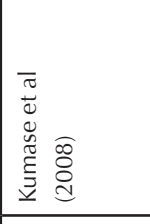 & 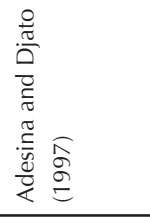 & 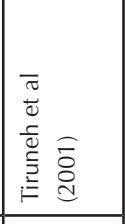 & 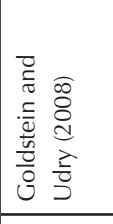 \\
\hline 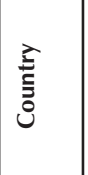 & & 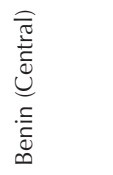 & 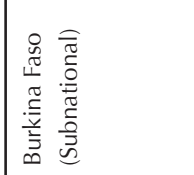 & 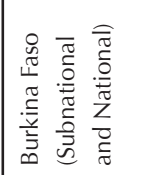 & 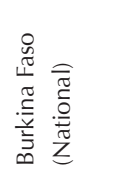 & 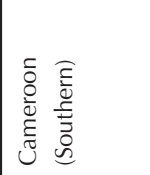 & 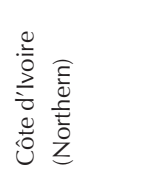 & 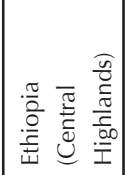 & 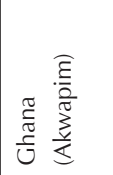 \\
\hline
\end{tabular}




\begin{tabular}{|c|c|c|c|c|c|c|c|c|}
\hline 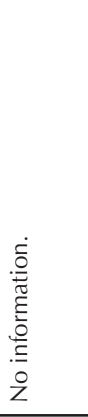 & 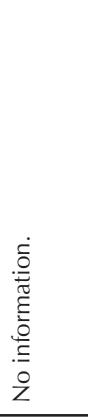 & 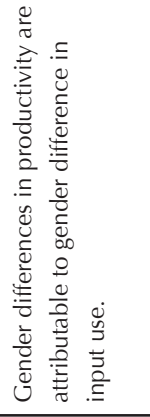 & 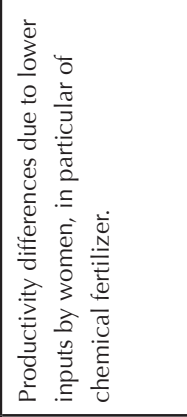 & 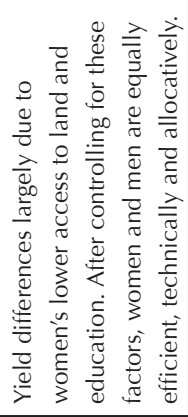 & 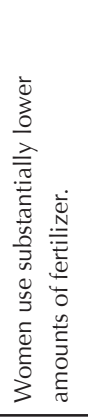 & 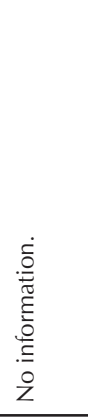 & 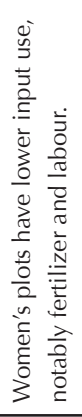 & 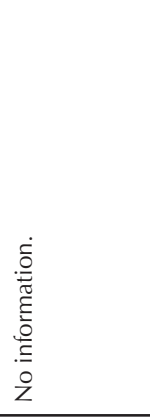 \\
\hline 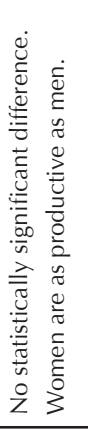 & 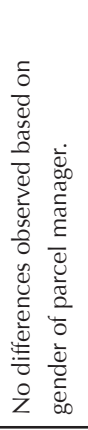 & 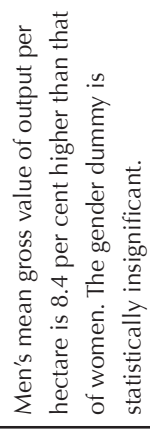 & 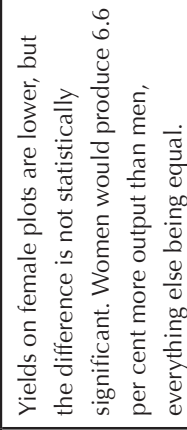 & 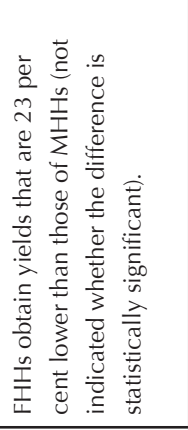 & 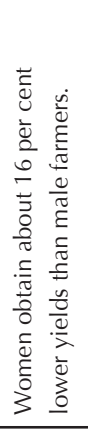 & 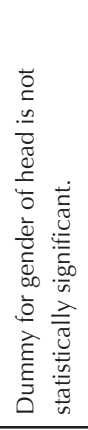 & 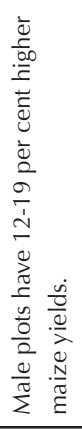 & 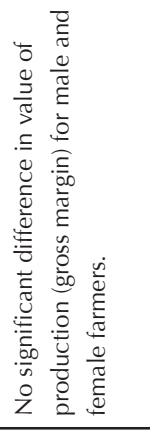 \\
\hline $\begin{array}{l}\pi \\
8 \\
8 \\
ن\end{array}$ & $\begin{array}{l}\tilde{0} \\
\stackrel{8}{0}\end{array}$ & 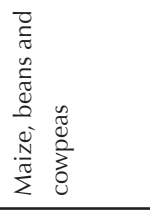 & $\frac{\stackrel{N}{\pi}}{\sum}$ & $\stackrel{\stackrel{N}{N}}{\sum}$ & $\stackrel{\stackrel{N}{N}}{\sum}$ & 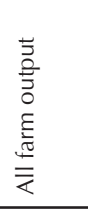 & $\frac{\stackrel{N}{N}}{\sum}$ & 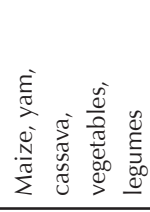 \\
\hline 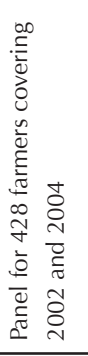 & 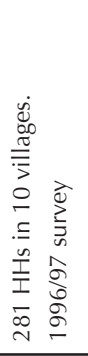 & 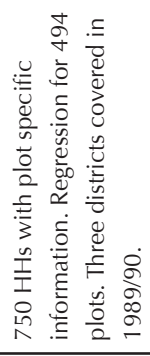 & 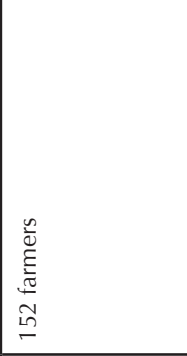 & $\begin{array}{l}\frac{n}{1} \\
\frac{1}{T} \\
8 \\
\& \\
\infty\end{array}$ & 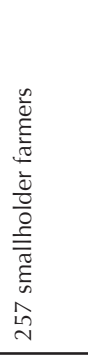 & 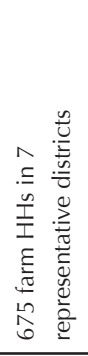 & 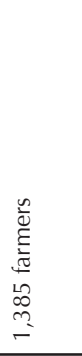 & 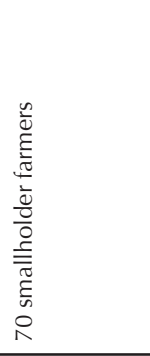 \\
\hline 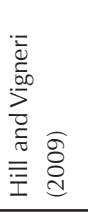 & 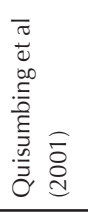 & 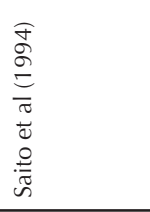 & 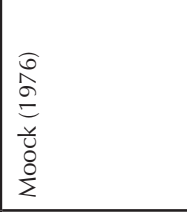 & 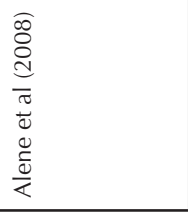 & 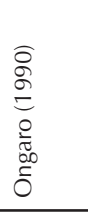 & 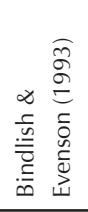 & 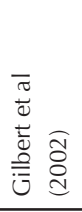 & 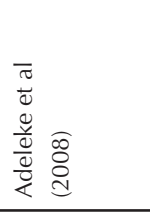 \\
\hline 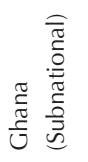 & 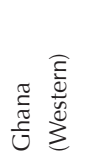 & 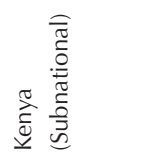 & 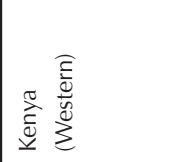 & 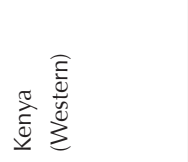 & 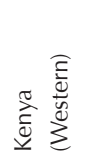 & 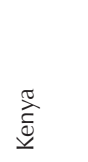 & 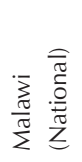 & 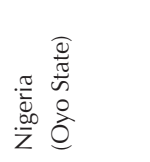 \\
\hline
\end{tabular}




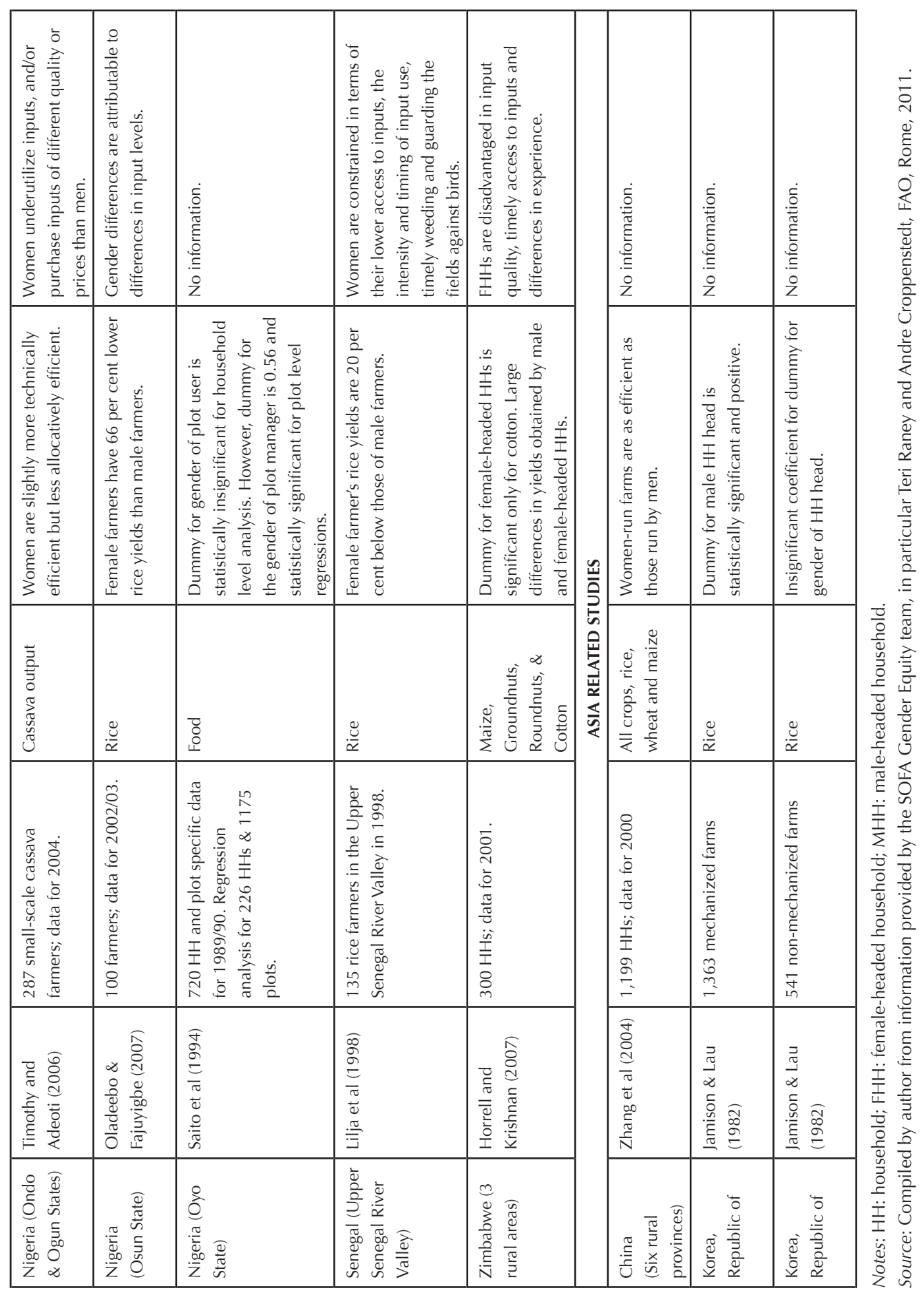


The findings are notable. Several studies find no statistically significant difference in managerial efficiency by the gender of the farmer, in terms of crop yields or production. Some show mixed effects, with no significant impact at the household level but significant impact by the gender of the plot manager (see e.g. Saito et al. 1994 for Nigeria). The majority of studies, however, find lower yields on women's plots/farms. This is not attributable, however, to women's lesser capability as farmers but to one or more of the following constraints: women's lower access to inputs, especially fertilizers; insecure land rights; lower access to male labour, oxen, and extension services; and difficulties in ensuring timely ploughing, weeding, or transportation. A few studies also demonstrate that if women had access to the same inputs and extension services as men, they would have higher outputs than male farmers. In Kenya, Dey (1992) found maize yields to be almost 7 per cent more on female-managed farms than on male-managed ones, when they had the same access to extension. In Burkina Faso, Udry et al. (1995) estimated that output could be increased by 10-15 per cent if factors of production (such as manure and fertilizers) were reallocated from men's plots to women's plots in the same household. Quisumbing (1996) concludes that if Kenyan women farmers had had the same access as male farmers to agricultural inputs and experience, their crop yields could have been raised by up to 23 per cent. This could have led to a doubling of Kenya's GDP growth rate from 4.3 per cent to 8.3 per cent in 2004 (World Bank 2009: 16).

There can also be an intra-household incentive effect if women control the products of their labour. In Kenya, for instance, the introduction of weeding technology in maize production raised yields on women's plots by 56 per cent where women controlled the output, and only by 15 per cent on the men's plots where too women weeded but men got the proceeds (Elson 1995). Since men tend to use more inputs and should therefore produce more output, this substantial difference may be seen as a disincentive effect when women do not receive compensation for their efforts within the family.

Studies in Asia are more sparse, but existing ones show that women farmers are as productive as male farmers (Table 1) or would be as productive with the same access to inputs and services (see Thapa 2008 for Nepal). Also illustrative is a rare study from rural India that examined the productive efficiency of men and women in using potato-digging equipment. It found women to be several times more productive, by all the measures used: women and men took 69 and 185 hours respectively for the same job, and women's potato-digging yield rate was $23.9 \mathrm{~kg}$ per 20 metre while men's was $18.2 \mathrm{~kg}$ per metre (Agarwal 1983: 56). Moreover, in South Asia, groups of women, farming collectively, have helped to bring large tracts of fallow land under cultivation and enhanced household and community food security (see Agarwal 2003 and Section 7 of this paper).

The overwhelming conclusion derived from the existing body of work is therefore twofold. On the one hand, if women had the same access to inputs as men, production would increase substantially on their farms. According to FAO's 2011 State of Food and Agriculture 
Report, reducing the constraints faced by women farmers could raise yields on their farms by 20-30 per cent and raise total agricultural output in developing countries by 2.5-4 per cent, thus making a significant impact on food availability (FAO 2011). On the other hand, if we fail to bridge the gender gaps in access to production inputs and services, the growing proportion of women in farming is likely to remain confined to low-productivity agriculture. Infrastructure development and other measures taken to revive agriculture would fail to reach them. In turn, this would undercut world potential for increasing agricultural output and ensuring food security. The situation would be exacerbated by the predicted effects of climate change, which will impinge negatively on the incomes and nutrition of millions of poor farmers, and specially women and children.

\section{WOMEN AS FOOD CONSUMERS AND HOUSEHOLD FOOD MANAGERS}

The second face of food insecurity is the lack of access to food, despite aggregate availability. There are high inequalities in food access across countries, within countries, and within households. By FAO's calculations for 2001-2003, there are an estimated 854 million undernourished persons across the world, of which 820 million are in developing countries, largely due to poverty (FAO 2006).

An increase in small farm productivity can reduce poverty and increase food access among such households. But ensuring food security for agricultural labourers and non-farm workers who do not grow their own food will require enhancing their economic resources and employment so that they can buy adequate food; improving delivery systems, including rural roads, for transporting food where it is needed most; and establishing public distribution systems that work. Moreover, simply increasing household-level access is not enough, since there are undernourished women and female children even within non-poor families, due to well-known intra-household distributional inequalities in access to food and health care.

In addition, in many developing countries, non-marketed foods gathered from forests and commons provide an important supplement to diets and hence to food security. The degradation and decline of forests and commons, coupled with women's reduced access to common pool resources, means a fall in such supplements, especially in the diets of poor women (Agarwal 2010a). Food price spikes and climate change can further exacerbate these gender inequalities.

All this strongly points to the critical need to reduce gender-related inequalities in direct access to the means to acquire food. This is important in itself. But additionally, women's enhanced access can bring intergenerational benefits. Mothers who are well nourished during pregnancy and lactation enhance the life chances and growth abilities of their children. Assets and incomes in mothers' hands are also found to have substantially greater positive effects on the nutrition, survival, and health of children, than assets and incomes in fathers' hands. Moreover, women owning land face significantly lower risk of domestic violence, which in 
turn would reduce their own and their children's health and nutrition risks linked with such violence (Agarwal and Panda 2007).

Increasing women's direct access to food would, however, require a range of measures, such as raising the productivity of women farmers; improving the capacity of non-farm women to buy food by enhancing their incomes and assets; formulating policies to increase women's access to food gathered from common pool resources; and initiating schemes that directly raise food availability for women in poor households.

\section{INCREASING WOMEN'S FARM PRODUCTIVITY}

Increasing the productivity of women farmers is likely to need a range of measures, such as

- recognizing women as farmers and not simply as farm helpers;

- improving women's direct access to land and tenure security;

- increasing women's direct access to production credit, agricultural inputs, technology, information on improved agricultural practices, storage and marketing outlets;

- directing more agricultural research and development to crops that women cultivate, based on a better understanding of women's farming systems; and

- institutional innovations, such as promoting a group approach to farm investment and cultivation.

Let us consider each aspect in turn.

First, the dominant perception of women as farm wives/helpers rather than farmers can seriously affect the way in which assets, information, and productive inputs are directed to farming families. Based on this perception, farm-related services tend to be directed to household men rather than to women farmers themselves. Perception changes could be facilitated by gender-sensitization of government officials who deliver the services. In such sensitization, NGOs and the media could also play a role.

Second, improving women's direct access to land and assets will require acting on three major sources of land: the family (via gift, inheritance, or transfer of usufruct rights), the State (via land transfers), and the market (via purchase or lease). Access via families depends especially on inheritance laws and their effective implementation. Such laws are gender-equal or moving in that direction in many countries, especially in Asia and Latin America, while remaining unequal in others. In India, for instance, where inheritance laws vary by religion, the 2005 amendment of the Hindu Succession Act made inheritance laws relating to all property, including agricultural land, gender-equal, for over 80 per cent of Indian women who are Hindus (Agarwal 2005a). Laws relating to Christians and Parsis had already been amended to make them gender-equal, but inequalities remain for Muslims and tribal communities (Agarwal 2005b). There are also substantial gaps between de jure and de facto rights in most countries due to poor implementation of laws and social barriers, including male bias in bequeathing 
property within families. Exceptions include countries such as Bhutan, where women own an estimated 70 per cent of the land (FAO n.d.-b.), and Sri Lanka, where most women from landed families inherit some land, even if unequal to men (Agarwal 1994). The effective implementation of laws will require not only transforming social norms and attitudes, but also spreading legal literacy, providing legal aid, and gender-sensitizing land registration officials and the judiciary.

In countries where land access is dependent on customary practices and mediated via clans or families, as is common in many communities of sub-Saharan Africa, and where women (as noted) are among the main food producers, increasing security of tenure on an individual basis is likely to prove more difficult (see also Saito, et al. 1994). Here, efforts at creating group rights for women (as discussed below) may be more effective.

The state and the market are important additional sources of immovable assets for women. At present, agricultural land distributed by governments under their anti-poverty, land reform, or resettlement schemes goes largely to men and only limitedly to women, either individually or jointly with husbands. Land titles transferred solely to women could go some way toward compensating for male bias in inheritance. Governments can also facilitate women's market access to land through subsidized grant-cum-credit schemes for purchasing or leasing in land. In particular, facilitating land leasing for women who are still dependent on agriculture is important, as men move to non-farm jobs, and educated children want to exit farming. For this, innovative institutional arrangements will be needed, since formal land leasing is often difficult, especially due to laws that bar such leasing (as in many states of India), or because landlords fear that tenants, if formally recognized, will acquire rights over their land. Typically, therefore, small tenants depend on informal leasing of small plots for short periods on exploitative terms. Here, alternative institutional forms would help.

One such form could be a public land bank (PLB) established the level of a village council, as recommended in India by the Twelfth Five Year Plan 'Working Group on Disadvantaged Farmers, including Women'. Under this proposal (see Agarwal and Sharma 2012), owners wanting to lease out their land would 'deposit' it in the PLB for a specified period (say, a year or more), on a voluntary basis, with the freedom to withdraw it with due notice. They would get a small payment on deposit (varying by period of deposit) and a share of the rent should the land be leased out. The PLB could lease the land to designated categories of farmers, such as marginal farmers and women. It would provide a guaranteed lease for a defined period in a consolidated plot of reasonable size, where possible; a calibration of rent with land quality; and a reduction in the uncertainty faced by poor farmers in negotiating leases, sometimes from several owners, to get a viable area. The PLB would thus reduce individual transactions costs for both lessors and lessees, help match land demand and supply, and especially benefit women who tend to get exploited in an unregulated lease market. In could also facilitate land development. 
Third, women farmers' access to credit, production inputs, technical information and marketing outlets needs substantial improvement. A range of measures could help, such as enhancing women's membership in credit and service cooperatives where these exist, and creating all-women service cooperatives that provide inputs and marketing support; gendersensitizing providers of technical information to farmers, with a clear emphasis on reaching women farmers; directly training women in new farm practices; and creating special service stations with designated officers to cover groups of villages, whom women could request to provide training, crop information, and support for input purchase and marketing (for elaboration, see Gol 2011).

Fourth, agricultural research and development (R\&D) efforts would be more effective if R\&D institutions as well as extension services worked with a better understanding of women's farming systems, including multi-cropping practices. This is especially needed in parts of Africa, where there are notable differences in the crops grown mainly by women and those grown mainly by men. Doss (2001), for instance, after reviewing an extensive literature on African women farmers, covering 25 years, emphasizes the need for developing technologies and crop varieties that take account of the constraints women farmers face. Devising effective ways of delivering extension advice on new agricultural practices is also important (Gilbert, Salaka and Benson 2002), as are efforts to design technology dissemination programmes which recognize women's constraints and local contexts. Five agencies in sub-Saharan Africa, for instance, helped large numbers of women adopt improved technology by using existing women's networks to identify women's needs and reach them quickly; consulting potential beneficiaries to identify their constraints; developing and selecting appropriate technology to overcome those constraints; and paying special attention to poorer women (Saito et al. 1994: 69).

Fifth, the effectiveness of all these measures could be enhanced by institutional innovations in the form of group approaches to farming. There are many potential advantages of women working together in small groups. At a minimum, across a village or ecological zone, women could benefit through cooperation in crop planning and pooling their finances to buy inputs, machinery and crop insurance. Groups can also improve women's clout with government agencies and so increase their access to formal credit, inputs and information (Braverman et al. 1991). Most importantly, groups can substantially raise women's chances of accessing land by enlarging their financial pool as well as their bargaining power in land purchase and lease markets. This process could be furthered by state-subsidized credit to groups of women for land purchase or lease.

However, it is with group farming based on pooling owned or leased land that we would expect the most gains in productivity and social empowerment compared with single family units. Potentially, it could help small holders take advantage of economies of scale; spread the risks of farming among a larger number; facilitate experimentation with higher value, more 
risk-prone crops with larger payoffs; enlarge scope for crop diversification; allow labour sharing; and bring together a greater diversity of talents, knowledge, and managerial skills. Labour shortages during peak seasons could also be overcome more effectively, both because more labour would be available within the group and because labour could be saved (Foster and Rosenzweig 2010). Moreover, a group would be better placed to enter into non-exploitative contract farming arrangements that (as noted) typically exclude small farmers and women, or include them under exploitative conditions. Within a group, it would also be easier to transfer knowledge about improved farming techniques to a second generation, especially to adolescent girls who could be future farmers and farm managers. In addition, groups would deal better with short-term shocks, such as rising input prices, and the long-term effects of climate change. Collective effort is necessary, for instance, for conserving soils, water and forests. Potentially, these benefits of joint investment and cultivation can extend to both landowners and land lessees. Socially, working in a group can help women overcome disabling social norms that restrict their public interactions in conservative cultures by drawing on the support of other women. In community forest management, for instance, women are found more likely to attend meetings, speak up for their interests, and take on leadership roles, where they constitute a critical mass of 25-30 per cent of the group members (Agarwal 2010a, 2010b).

Overall, therefore, as a group, we would expect the poor to be better protected, both as producers and as consumers. As producers, they would have better prospects of overcoming their production constraints and moving from being deficit to surplus farmers. As consumers, they could more effectively undertake income-smoothing and enjoy welfare benefits. Can this potential be fulfilled in practice? Known examples of group farming suggest so.

There are diverse examples of small farmers cooperating successfully, including for joint planning and investment in farm inputs, collective marketing of produce via cooperatives and producer companies, joint investment in irrigation and other lumpy inputs, and most particularly, group farming by pooling owned, purchased or leased-in land and other resources. Successful group farming with land pooling can be found especially in transition economies and in parts of South Asia. The groups are constituted of families in the former and of poor rural women in the latter (see Agarwal 2010c for details).

Countries in Central Asia and Eastern Europe that undertook large-scale collectivization during the 1950s to 1970s de-collectivized in the 1980s and 1990s, thus enabling farmers to revert to individual family farming. However, many families in countries such as Kyrgyzstan, Romania, and East Germany voluntarily chose to form new group enterprises (with friends, relatives or neighbours) by pooling their land and other resources to farm collectively on the restituted land or by continuing in much downsized former collectives. Productivity in these group enterprises is found to be significantly higher than in individual family farms, since as a group they could overcome constraints arising from small land size, or labour shortages, or lack of access to machinery, and so on. 
In the second type of examples, drawn mainly from India, the groups are constituted only of women. The earliest initiative relates to Andhra Pradesh in south India and dates from the 1980s. With the support of the Deccan Development Society (DDS, an NGO), poor, low-caste women in drought-prone Medak district have been leasing in or purchasing land in groups of five to fifteen women, through various government schemes that provide subsidized credit and/or grants (Agarwal 2003, 2010c). The land is then cultivated collectively. The aim is to ensure food security in an environmentally friendly way, through organic farming and multiple cropping. In 2008, the group leasing programme covered 26 villages, cultivating around 85 hectares (ha). In addition, 25 women's groups were cultivating about 225 ha of purchased land in 21 villages. This land had been bought through a grant-cum-credit scheme of the state government, meant to help poor women purchase land as a group. The land is registered in equal portions in individual women's names but cultivated jointly. These women would not have been able to buy land or use it as productively on an individual basis. The groups are voluntary in nature, socio-economically homogenous, constituted of women who know each other, small in size, participatory in decision-making, and equitable in task sharing and distribution of produce. Standard collective action problems are solved by peer review at weekly meetings. Some groups grow up to 24 crop varieties a year (the seeds of which they preserve), thus reducing the risk of total crop failure and providing a balanced diet. Group members report that working together has enhanced their ability to overcome production constraints, meet government officials, and enjoy flexibility in labour time. They also report an improvement in family diets and healthcare, among other benefits.

Other examples of group farming can also be found in South Asia. In Andhra Pradesh, India, for instance, through a different initiative from that of DDS, around 7500 women farmers are farming in groups of 25-30 women each, on about 425 ha of dryland in 250 villages. The land is typically obtained on lease, but some women also pool their own land which was uncultivated due to input constraints. The initial impetus for group formation was provided by a five-year project begun in 2000 by the UNDP and the Government of India involving 42,000 women living in around 1000 villages in three states (Burra 2004). Even after the project ended, however, the groups have continued in many villages under other arrangements. Another notable example is the Kudumbashree programme launched by the Government of Kerala (south India) for supporting landless and land-poor women to lease in land for group farming. Additionally, since 2010, the Joint Liability Group (JLG) scheme of NABARD (National Bank for Agriculture and Rural Development) has helped link the groups with subsidized credit. There are reported to be several thousand women leasing in land for group farming in all districts of the state. The community has also gained, since the women's groups have brought substantial fallow land into cultivation. In Bangladesh too, we can find examples of women's groups leasing in land for joint cultivation. These are found to have notable growth potential, if provided support such as adequate credit. 
The above examples demonstrate in different ways the potential of small farmers voluntarily working together in groups for the output and food security gains they bring and the resource constraints they help overcome. In sub-Saharan Africa, where communal systems of land ownership are still widespread, the possibility of women farming collectively warrants similar exploration. We need to know much more, however, about the factors which are most conducive to sustainable group formation; the productivity benefits (carefully measured) of these groups; and the potential for their geographic growth, say by encouraging existing women's groups, such as India's self help groups (SHGs)—of which there are over 2.5 million— to take up joint ventures.

\section{WOMEN AS CONSUMERS AND FOOD MANAGERS: IMPROVING ACCESS}

Women's role in mitigating hunger for themselves and their families will be served to an important extent by increasing their access to assets and land, and enhancing their farm productivity and control over incomes. But there are also large numbers of women (rural and urban) who depend for their food security on wage employment and non-farm selfemployment. Here, food security is linked directly to how many jobs go to women, and whether the schemes that provide work are directed at women.

In recognition of the special role women play in mitigating family hunger, some countries have initiated measures that directly increase women's resources, such as making conditional cash transfers to women in Latin America (World Bank 2001) or the Mahatma Gandhi National Rural Employment Guarantee Act (MNREGA) in India, which guarantees 100 days of employment for one person per household. Although not specifically directed at women, MNREGA has attracted a large number of women: a study of six states found that women constituted 32 per cent of the MNREGA workers on average (Khera and Nayak 2009: 52).

Many of the general schemes being discussed by governments and international agencies for enhancing food security could also gain from the greater involvement of women. In Andhra Pradesh, for example, federations of women's SHGs have been buying foodgrain in bulk and selling them to poor members at a nominal price or on short-term credit, thus contributing to income-smoothing (Nair and Shah 2007). Recent studies show that 55-60 per cent of SHG members are poor and socially disadvantaged (EDA 2006, NCAER 2008), but even when the SHGs are not constituted mainly of the poor, they can reach the poor. The DDS women's groups, described earlier, have also set up community grain banks (Agarwal 2003). All this suggests that women's groups could prove effective in creating local buffer stocks and regional food banks and in improving the public distribution systems networks if they had access to infrastructure for food storage and distribution. Women-inclusive forest governance can also bring substantial gains both in terms of improved conservation outcomes and women's greater access to gathered food items (Agarwal 2010a). 
Essentially, viewing agriculture and related sectors through the lens of gender will reveal the many ways in which women farmers are contributing to food systems globally, and help pinpoint mechanisms for making their efforts more effective. This would also improve the chances of achieving several millennium development goals, such as ending poverty and hunger, increasing gender equality, and improving child health and maternal health.

An additional challenge lies in improving the statistical base for assessing and monitoring gender-differentiated access to land, farm credit, inputs, technical information and marketing, as well as monitoring nutrition and health indictors for women and children in both poor and non-poor households.

\section{CONCLUDING COMMENTS}

Ensuring food security is both the most basic of development issues and the most complex. Gender inequalities are a significant part of the problem and reducing those inequalities will be a critical part of the solution. The inequalities women face as producers reduce the potential productivity of agriculture and hence of overall food availability in countries, regions, and worldwide. It does so both by failing to take into account the specific constraints that women farmers face, even as dependence on women farmers grows, and by failing to recognize that in particular contexts the productivity gains would be higher if existing inputs were directed at women. Estimates indicate the potential of substantial productivity gains from bridging gender gaps in land security and access to inputs and services. However, this will need not only technical and financial support, but also institutional innovation, including more group approaches to farm investment and management.

Similarly, the inequalities women face as consumers adversely affects both their own well-being as well as that of future generations of children who inherit the disabilities arising from poor maternal health. Reducing inequalities embedded in women's access to incomeearning opportunities and productive assets would not only benefit women themselves but also their children, by enhancing women's bargaining power within the home and so their ability to direct more household resources to children's well-being.

Reducing gender inequalities faced by women as farmers and workers is therefore an imperative both for its intrinsic importance and for its wider implications. Doing so could prove to be a wise strategy for tackling food crises and creating a food-secure world. 


\section{REFERENCES}

Adeleke, O.A., O.I. Adesiyan, O.A. Olaniyi, K.O. Adelalu, and H.M. Matanmi (2008). Gender Differentials in the Productivity of Cereal Crop Farmers: A Case Study of Maize Farmers in Oluyole Local Government Area of Oyo State. Agricultural Journal, 3 (3): 193-198.

Adesina, A. A. and K.K. Djato (1997). Relative Efficiency of Women as Farm Managers: Profit Function Analysis in Côte d'Ivoire. Agricultural Economics, 16 (1): 47-53.

Agarwal, B. (1983). Mechanization in Indian Agriculture. Allied Publishers: New Delhi.

Agarwal, B. (1990). Social Security and the Family: Coping with Seasonality and Calamity in Rural India. The Journal of Peasant Studies, 17 (3): 341-412.

Agarwal, B. (1994). A Field of One's Own: Gender and Land Rights in South Asia. Cambridge University Press, Cambridge.

Agarwal, B. (2000). Participatory Exclusion, Community Forestry and Gender: An Analysis and Conceptual Framework. World Development, 29 (10): 1623-1648.

Agarwal, B. (2003). Gender and Land Rights Revisited: Exploring New Prospects via the State, Family and Market. Journal of Agrarian Change, 3 (1-2): 184-224.

Agarwal, B. (2005a). A Landmark Step to Gender Equality. The Hindu, Sunday Magazine, 25 September.

Agarwal, B. (2005b). Women's Inheritance: Next Steps. Indian Express, 17 October.

Agarwal, B. (2010a). Gender and Green Governance: The Political Economy of Women's Presence Within and Beyond Community Forestry. Oxford University Press: Oxford.

Agarwal, B. (2010b). Does Women's Proportional Strength Affect their Participation? Governing Local Forests in South Asia. World Development, 38 (1): 98-112.

Agarwal, B. (2010c). Rethinking Agricultural Production Collectivities. Economic and Political Weekly, 27 February, 55 (9): 64-78.

Agarwal, B. (2011). 'Food Crises and Gender Inequality', Working Paper No 107, United Nations Department of Economic and Social Affairs, New York.

Agarwal, B. and P. Sharma (2012). 'An Idea to Bank On', Times of India, edit page, 12 January.

Agarwal, B., and P. Panda (2007). Toward Freedom from Domestic Violence: The Neglected Obvious. Journal of Human Development, 8 (3): 359-388.

Akresh, R. (2008). (In)Efficiency in Intra-household Allocations. Working Paper, Dept. of Economics, University of Illinois at Urbana Champaign. 
Alene, A .D., V.M. Manyong, G.O. Omanya, H.D. Mignouna, M. Bokanga and G.D. Odhiambo (2008). Economic Efficiency and Supply Response of Women as Farm Managers: Comparative Evidence from Western Kenya. World Development, 36 (7): 1247-1260.

Allendorf, K. (2007). Do Women's Land Rights Promote Empowerment and Child Health in Nepal? World Development, 35 (11): 1975-1988.

Anriquez, G. À Paraître (2010). Rural Feminization and the Gender Burden: A Cross-country Examination. background paper, 2011 State of Food and Agriculture Report (SOFA Report), FAO, Rome.

Bindlish, V., R. Evenson and M. Gbetibouo (1993). Evaluation of T and V-based extension in Burkina Faso. World Bank Technical Paper No. 226, Africa Technical Department Series, World Bank, Washington, DC.

Braverman, A., J. L. Guasch, M. Huppi, and L. Pohlmeier (1991). Promoting Rural Cooperatives in Developing Countries. Discussion Paper No. 121, World Bank, Washington DC.

Burra, N. (2004). Empowering Women for Household Food Security: UNDP's Experience. United Nations Development Programme, Delhi.

Collins, J. L. (1993). Gender, Contracts and Wage Work - Agricultural Restructuring in Brazil's Sao Francisco Valley. Development and Change, 24 (1): 53-82.

Deere, C. D., and Magdalena de Leon (2001). Empowering Women: Land and Property Rights in Latin America. University of Pittsburgh Press: Pittsburgh.

Deere, C. D. and C. R. Doss (2006). The Gender Asset Gap: What Do We Know and Why Does it Matter? Feminist Economics, 12 (1-2): 1-50.

Dey, J. (1992). Gender Asymmetries in Intra-Household Resource Allocation in sub-Saharan Africa: Some Policy Implications for Land and Labour Productivity. Paper presented at IFPRI workshop on Intra-Household Resource Allocation.

Dolan, C. S. (2001). The 'Good Wife': Struggles over Resources in the Kenyan Horticultural Sector. Journal of Development Studies, 37 (3): 39-10.

Doss. C. R. (2001). Designing Agricultural Technology for African Women Farmers: Lessons from 25 Years of Experience. World Development, 29 (12): 2075-2092

Doss, C. R. (2010). If Women Hold Up Half the Sky, How Much of the World's Food Do They Produce? Background paper, 2011 State of Food and Agriculture Report (SOFA Report), FAO, Rome.

EDA (2006). Self Help Groups in India: A Study of Lights and Shades, mimeo, EDA Rural Systems Private Ltd. Gurgaon, and Andhra Pradesh Mahila Abhivruddhi Society, Hyderabad. 
Elson, D. (1995). Gender Awareness in Modelling Structural Adjustment. World Development. 23 (11): 1851-1868.

Estudillo, J. P., A. R. Quisumbing and O. Keijiro (2001). Gender Differences in Land Inheritance and Schooling Investments in the Rural Philippines. Land Economics, 77 (1): 130-143.

FAO (2006). The State of Food Insecurity in the World. Food and Agricultural Organization, $\mathrm{FAO}$, Rome.

FAO (2011). The State of Food and Agriculture. FAO, Rome.

Foster, A.D., and M.R. Rosenzweig (2010). Is There Surplus Labour in Rural India. Discussion Paper No. 991, Economic Growth Center, Yale University, New Haven.

Gilbert, R. A., W. D. Sakala and T .D. Benson (2002). Gender Analysis of a Nationwide Cropping System Trial Survey in Malawi. African Studies Quarterly, 6 (1-2): 223-243.

Gol (Government of India). 1995-1996 Agricultural Census of India. Ministry of Agriculture, Gol, New Delhi.

Gol (2006). Census of India 2001: Population Projections for India and States 2001-2026, Report of the technical group on population projections, National Commission on Population, Gol, Delhi.

Gol (2011). Report of the Twelfth Plan Working Group on Disadvantaged Farmers, Including Women, Chaired by Bina Agarwal, Planning Commission, Gol, New Delhi.

Goldstein, M. and C. Udry (2008). The Profits of Power: Land Rights and Agricultural Investment in Ghana. Journal of the Political Economy, 116 (6): 981-1022.

Hill, R .V. and M. Vigneri (2009). Mainstreaming Gender Sensitivity in Cash Crop Market Supply Chains. Background paper, 2011 SOFA Report. FAO, Rome.

Holden, S., B. Shiferaw and J. Pender (2001). Market Imperfections and Land Productivity in the Ethiopian Highlands. Journal of Agricultural Economics, 52 (3): 53-70.

Horrell, S., and P. Krishnan (2007). Poverty and Productivity in Female-headed Households in Zimbabwe. Journal of Development Studies, 43 (8): 1351-1380.

Ivanic, M., and W. Martin (2008). Implications of Higher Global Food Prices for Poverty in Low-Income countries. Policy Research Working Paper Series 4594, World Bank, Washington DC.

Jamison, D.T., and C. J. Lau (1982). Farmer Education and Farm Efficiency. Johns Hopkins University Press: Baltimore MD.

Jodha, N. S. (1986). Common Property Resources and the Rural Poor. Economic and Political Weekly, 21 (27): 1169-1181. 
NSSO (National Sample Survey Organisation) (2005). Employment and Unemployment Situation in India (July 2004 - June 2005), NSS 61th Round, NSSO, Gol, New Delhi.

IFAD (2009). Evaluation: Bangladesh. http://bit.ly/U7ITcE. Last accessed on 20 September 2012

IFPRI (International Food Policy Research Institute) (2009). Climate Change: Impact on Agriculture and Costs of Adaptation. IFPRI, Washington DC.

Khera, R. and N. Nayak (2009). Women Workers and their Perceptions of National Rural Employment Guarantee Act. Economic and Political Weekly, 44 (43), 24 October.

Kinkingninhoun-Mêdagbé, F. M., A. Diagne, F. Simtowe, A.R. Agboh-Noameshie and P.Y. Adegbola (2008). Gender discrimination and its impact on income, productivity and technical efficiency: Evidence from Benin. Agriculture and Human Values, 27 (1): 5769.

Kumar, P. (2006). Contract farming in India: Options and Implications for Small and Large Farmers. Institute of Economic Growth Working Paper No. E/267/2006.

Kumase, W.N., H. Bisseleua and S. Klasen (2008). Opportunities and Constraints in Agriculture: A Gendered Analysis of Cocoa Production in Southern Cameroon. Discussion Paper No. 27. Courant Research Centre, University of Göttingen.

Lastarria-Cornhiel, S. and A. Manji (2010). Land Tenure, Land Policy, and Gender in Rural Areas. background paper, 2011 SOFA Report, FAO, Rome.

Li, Z. (2003). Women's Land Tenure Rights in Rural China: A Synthesis. Mimeo, Ford Foundation, Beijing.

Lilja, N. K., T.F. Randolph and A. Diallo (1998). Estimating Gender Differences in Agricultural Productivity: Biases Due to Omission of Gender-Influenced Variables and Endogeneity of Regressors. Paper submitted to the American Agricultural Economics Association meeting, Salt Lake City, Utah, USA, 2-5 August.

Maertens, M. and J.F.M. Swinnen (2009). Are Modern Supply Chains Bearers Of Gender Inequality? Paper presented at the ILO-FAO workshop 'Gender Dimension of Rural Employment'. 30 March-3 April, Rome.

Mathijs, E. and J.F.M. Swinnen. 2001. 'Production Organization and Efficiency during Transition: An Empirical Analysis of East German Agriculture', Review of Economics and Statistics, 83 (1): 100-107.

Mazhar, F., D. Buckles, P. V. Satheesh and F. Akhter (2007). Food Sovereignty and Uncultivated Biodiversity in South Asia. IDRC, Ottawa.

Moock, P.R. (1976). The Efficiency of Women Farm Managers Kenya. American Journal of Agricultural Economics, 58 (5): 831-835 
Nair, A. and P. Shah (2007). Self help Works. Times of India, 27 December.

NCAER (2008). Impact and Sustainability of SHG Bank Linkage Programme (New Delhi: National Council of Applied Economic Research).

Oladeebo, J.O., and A .A. Fajuyigb (2007). Technical Efficiency of Men and Women Upland Rice Farmers in Osun State, Nigeria. Journal of Human Ecology, 22 (2): 93-100.

Ongaro, W.A. (1990). Modern Maize Technology, Yield Variations and Efficiency Differentials: A Case of Small Farms in Western Kenya. Eastern Africa Economic Review, 6 (1): 11-29.

Peterman, A., J. Behrman and A. R. Quisumbing (2009). A Review of Empirical Evidence on Gender Differences in Non-Land Agricultural Inputs, Technology and Services in Developing Countries. Background paper, 2011 SOFA Report, FAO, Rome.

Quisumbing, A. R. (1996). Male-Female Differences in Agricultural Productivity: Methodological Issues and Empirical Evidence. World Development, 24 (10): 15791595.

Quisumbing, A. R. and J.A. Maluccio (2000). Intra-household Allocation and Gender Relations: New Empirical Evidence. Discussion Paper, IFPRI, Washington DC.

Quisumbing, A.R., Ellen Payongayong, J.B. Aidoo and Keijiro Otsuka (2001). Women's Land Rights in the Transition to Individualized Ownership: Implications for the Management of Tree Resources in Western Ghana. Economic Development and Cultural Change, 50 (1): 157-182.

Quisumbing, A.R., R.S. Meinzen-Dick, L. Bassett, M. Usnick, L. Pandolfelli, C. Morden and H. Alderman, (2008). Helping Women Respond to the Global Food Price Crises. Policy Brief 7, IFPRI, Washington DC.

Runsten, D., and N. Key (1996). Contract Farming in Developing Countries: Theoretical Aspects Analysis of some Mexican Cases. Economic Commission for Latin America and the Caribbean, RLC/96/14-RLCP-01.

Saito, K.A., H. Mekonnen and D. Spurling (1994). Raising the productivity of women farmers in sub-Saharan Africa. World Bank Discussion Papers, Africa Technical Department Series No. 230, World Bank, Washington DC.

Sabates-Wheeler, R. 2002. 'Farm Strategy, Self-Selection and Productivity: Can Small Farming Groups Offer Production Benefits to Farmers in Post-Socialist Romania', World Development, 30 (10): 1737-1753.

Sabates-Wheeler, R. and M. D. Childress. 2004. 'Asset-pooling in Uncertain Times: Implications of Small-group Farming for Agricultural Restructuring in the Kyrgyz Republic', Working Paper 239, Institute of Development Studies, Sussex. 
Singh, S. (2000). Theory and Practice of Contract Farming: A Review. Journal of Social and Economic Development, 3 (2): 228-246.

Strauss, J., and K. Beegle (1996). Intra-household Allocations: A Review of Theories, Empirical Evidence and Policy Issues. MSU International Development Working Paper No. 62, Dept. of Agricultural Economics, Michigan State University, East Lansing.

Thomas, D. (1990). Intra-Household Resource Allocation: An Inferential Approach. Journal of Human Resources, 25 (4): 635-663.

Thomas, D. (1994). Like Father Like Son, or, Like Mother Like Daughter: Parental Education and Child Health. Journal of Human Resources, 29 (4): 950-988.

Thapa, S. (2008). Gender Differentials in Agricultural Productivity: Evidence from Nepalese Households Data. Munich Personal ReREC Archive, MRPA Paper No. 13722.

Timothy, A .T. and A. I. Adeoti (2006). Gender Inequalities and Economic Efficiency: New Evidence from Cassava-based Farm Holdings in Rural South-western Nigeria. African Development Review, 18 (3): 428-443.

Tiruneh, A., T. Tesfaye, W. Mwangi and H. Verkuijl (2001). Gender Differentials in Agricultural Production and Decision-making Among Smallholders in Ada, Lume and Gimbichu Woredas of the Central Highlands of Ethiopia. International Maize and Wheat Improvement Center and Ethiopian Research Organization.

Udry, C., J. Hoddinott, H. Alderman and L. Haddad (1995). Gender Differentials in Farm Productivity: Implications for Household Efficiency and Agricultural Policy. Food Policy, 20 (5): 407-423.

von Braun, J. (2008). Rising Food Prices: What Should be Done? Eurochoices, 7 (2): 30-35.

von Braun, J. (2008-09). Food Security Risks Must be Comprehensively Addressed, Annual Report Essay 2008-09, IFPRI, Washington DC.

World Bank (2001) Brazil: An Assessment of the Bolsa Escula Programs. Report No. 20208BR. World Bank, Latin America and the Caribbean Regional Office.

World Bank (2007). World Development Report 2008: Agriculture for Development. World Bank: Washington DC.

World Bank (2009). Gender in Agriculture Sourcebook. Vols 1 and 2. World Bank, Washington DC.

Zhang, L., A. de Brauw and S. Rozelle (2004). China's Rural Labor Market Development and its Gender Implications. China Economic Review, 15 (2): 230-247. 
